Gyekye-Jandoh / Legon Journal of the Humanities (2017) 46-61

DOI: https://dx.doi.org/10.4314/ljh.v28i1.5

\title{
The Role of the International Community in Ghana's Democratic Transition in the 1990s
}

\author{
Maame Adwoa Gyekye-Jandoh \\ Senior Lecturer, Department of Political Science, \\ University of Ghana, Legon, Ghana \\ mgyekye-jandoh@ug.edu.gh / mgyekyej@yahoo.com
}

Submitted: June 13, 2016 / Accepted: November 14, 2016 / Published: May 31, 2017

\begin{abstract}
This article argues that Ghana's democratization took place through a two-stage process, where the first stage saw the international community play a more dominant role leading up to Ghana's transition in 1992. Rawlings' decision to democratize was the outcome of a rare convergence of domestic and international pressures. In the first stage, international forces provided the structural context for political reform. There are two facets of the international impact: snowballing/demonstration effect, and implicit political conditionality. Evidence is given to show that it was only when snowballing and implicit political conditionality held sway over Rawlings that the transition to democracy was given a boost.
\end{abstract}

Keywords: international community, Ghana, democratic transition, snowballing, political conditionality

\section{Introduction and Background}

In many respects, the case of Ghana's transition to Western democracyin the 1990s is an unusual one, because none of the recent standard explanations of how the international community impacts regime change works there. For example, Levitsky and Way's $(2003,2005)$ works on the role of international factors in regime change demonstrated that both Western leverage and linkage to the West raised the cost of authoritarianism during the post-Cold War period, in hybrid or competitiveauthoritarian regimes. Diplomatic pressure, or conditionality, two mechanisms of "leverage" were, however, insufficient for authoritarian regimes to democratize; "linkage", with its more subtle and diffuse effects, rather contributed more consistently to democratization. Western leverage meant governments' vulnerability to external pressure, while linkage meant the density of a country's ties to the U.S., the European Union, and Western multilateral institutions (Levitsky \& Way, 2003; Levitsky \& Way, 2005).

If this new framework helps one to understand many cases, it does not completely work in Ghana's case, because while "leverage" did indeed raise the cost of authoritarian acts such as repression of demonstrations in Ghana in the late 1980s and early 1990s, there is no evidence (except subtle un-measurable evidence, if any) that "linkage to the West" contributed immensely to democratization in Ghana. Thus the assertion by Levitsky and Way $(2005 ; 2010 ; 2012)$ that "linkage contributed more consistently to democratization" does not apply to Ghana. Rather, "leverage", in the form of conditionality, played a larger role in Ghana's democratic transition, and this buttresses the "leverage" aspect of the authors' framework.

While snowballing did have an influence on the occurrence and timeline of political liberalization events in Ghana, its implicit political conditionality through the PNDC's extensive engagement with the World Bank/International Monetary Fund (IMF) in implementing the Economic Recovery Program/Structural Adjustment Program (ERP/SAP) was the more dominant international factor in promoting democracy in Ghana. Having gained an international reputation as the "darling of

Legon Journal of the Humanities 28.1 (2017)

$\mathrm{P}$ a g e $\mid 46$ 
the Bank/IMF", Flight-Lieutenant John Jerry Rawlings did not want to risk this reputation through large-scale abuse or crackdown. As Nugent (1996, p. 202) has argued, there were three choices available to Rawlings at the point of transition: to dig in further by repressing opposition, to capitulate and let opposition forces take over the transition process, or to come up with fresh initiatives and take control of the political reform process, which by the late 1980s was definitely on the agenda.

Rawlings, as an agent constrained by structural forces (Bermeo, 1990; Przeworski, 1991), chose the last course, based on his "own long-range calculations" (Nugent 1996, p. 202), including protecting his international reputation and his regime's all-important need for continued foreign aid that came mostly from the Bank/IMF. The re-awakened, re-energized opposition movement was surprised by Rawlings' announcement of liberalizing reforms and the timing of these reforms. In so doing, he managed to retain the initiative and control of the transition process.

Implicit political conditionality promoted democracy in Ghana in two ways: by increasing popular demands due to the ERP/SAP's unpopularity, especially among urban workers and students in the late 1980s; and second, due to Ghana's increased dependence on foreign aid from the Bank/IMF. Increased dependence meant that the regime was more vulnerable to conditions that were placed on it for continued aid, in the form of calls for good governance (World Bank, 1989) as an important facilitator of economic reform.

Thus, the Ghana case involved a subtle puzzle, in which calls for democracy in particular were not an explicit part of World Bank/IMF conditionality. Nonetheless, the international factor still mattered because Rawlings' Provisional National Defense Council (PNDC) had invested massively in engaging with the Bank/IMF via the SAP and because of the attendant aid it received. The PNDC was in quite a tight position, because no other aid was forthcoming from its earlier allies, including Cuba, Libya, and even the former Soviet Union. It was widely believed that the PNDC could not survive to the end without the external assistance it received (Nugent, 1996, p. 187). This prognosis actually answers the counterfactual question, of what would have happened to the Rawlings-PNDC if foreign aid was no longer forthcoming. It most probably would not have survived its eleven years in office, as most of the funds used to provide infrastructure, give rents to those who supported it, bring the economy back from the brink, and build a political base that eventually helped it win the 1992 elections came from external sources, especially the Bank/IMF.

This paper's discussion shows that structural factors of the international system do have an impact on democratic transitions, as they constrain the choices of political actors, in Ghana's case, Rawlings, during the process of regime change (Skocpol, 1979; Haggard \& Kaufmann, 1995). The Ghana case shows that a combination of both structural (Skocpol, 1979; Levitsky \& Way, 2003; 2005) and contingent/voluntarist (Linz, 2000; Linz \& Stepan, 1978, 1996; Przeworski, 1991; Geddes, 1991; Diamond, Linz, \& Lipset, 1995) explanations are needed for both transition to democracy and further democratization. The international community worked in constraining Rawlings toward the transition by increasing the costs of crackdown, but it could not determine the choice he made. He could have capitulated to demands for democracy by giving up power and handing over to an interim government, but he gradually democratized, largely on his own terms rather than the opposition's. Rawlings also made the choice to engage the international environment in the 1980s, and this differentiates him and Ghana from other African countries that did not engage with the Bank/IMF or did not engage in a timely fashion.

Ghana's transition to democracy has attracted much interest from the academy. Boafo-Arthur (1998), for example, argues that Ghana's multilateral and bilateral donors leveraged her dependence on them financially and economically to bring about democratization. However, this current paper argues that leverage, in the form of "implicit political conditionality" 1 that raised the costs of authoritarian acts by the Rawlings' PNDC, as well as the impact of snowballing, i.e. increased liberalizing events in Ghana coinciding with liberalizing events in Eastern Europe, and the fall of the Soviet Union, led to the Ghanaian transition to democracy in 1993. The difference between this paper

In other words, unintended and not particularly pre-strategized or explicit push for democracy.

Legon Journal of the Humanities 28.1 (2017)

P a g e $\mid 47$ 
and others in the current literature is its combination, in one paper, of an analysis of the details of the conditionality dynamics of donors through the SAPs and increased aid with that of the snowballing, or impact of international environmental events on Ghana.

\section{Methodology}

The article employs a qualitative method of research through both primary and secondary data. The primary data consists of field interviews and analysis of newspapers and important statements and relevant documents, while the secondary data reviews relevant literature from books and journals. The article includes evidence to back its two main arguments. First is the analysis of the timeline and significance of important democratizing measures in Ghana taken by the Rawlings-PNDC and roughly paralleling liberalizing events in Eastern Europe, statements by Rawlings, and activists' statements on the importance of the international environment for the timing of Ghana's democratic transition furnish evidence of snowballing.

Evidence of World Bank/IMF political conditionality promoting democracy in Ghana is seen in increased popular demands for democratic rule from workers' and students' demonstrations and strikes in the late 1980s. An examination of the ERP/SAP and its successes and costs show why there was an increase in popular demands among these previous supporters of the PNDC. Data is also provided on the amount of Bank/IMF aid received by Ghana as a result of the Structural Adjustment Program (SAP), together with an analysis of the government's increased dependence on aid.

\section{Brief Political History of Ghana}

Ghana was the first African country south of the Sahara to gain independence from the British. It began its post-independence life on a very good pluralist democratic footing, having inherited the Westminster parliamentary system of government and constitution from the British. Its first democratically elected government was led by Kwame Nkrumah of the Convention People's Party (CPP) in 1957 (Ninsin, 1998). Ninsin (1998, p. 2) points out that multiparty politics and spirited public debate were key features of politics in Ghana both before and immediately after independence. Unfortunately, Ghana experienced its first coup d'état by senior military officers on February 24, 1966. Nkrumah was ousted, and the National Liberation Council (NLC) took power. Led by General A.A. Afrifa, the NLC handed over power to the democratically elected Progress Party (PP) government of Kofi Abrefa Busia on August 29, 1969.

Unfortunately, the pattern of civilian-military cycles set in motion in 1966 continued, with the PP government's overthrow on January 13, 1972 in a military coup, led by the National Redemption Council's (that later became SMC I in 1975) Lt-Col. I. K. Acheampong. On July 5, 1978, Acheampong was ousted in a palace coup by Lt-Gen. F.W.K. Akuffo, ushering in the Supreme Military Council (SMC II). The SMC II was in turn ousted by another coup, which successfully brought Flt-Lt. J.J. Rawlings, a junior officer, to power as head of the Armed Forces Revolutionary Council (AFRC) on June 4, 1979. With the coming of the AFRC, senior military officers were executed, including Acheampong and Akuffo. On September 24, 1979, Rawlings handed over power to Ghana's third civilian multiparty government, under the elected People's National Party (PNP) of Dr. Hilla Limann.

The pattern of military-civilian cycles continued with another military coup on December 31, 1981. The Provisional National Defence Council (PNDC) era was characterized by an authoritarian ruling strategy, which allowed the government to pursue an IMF-World Bank Structural Adjustment Program (SAP) almost to the letter, beginning in 1983, dubbed the Economic Recovery Program (ERP). The PNDC was in office for 11 years, until January 7, 1993, when after multiparty elections in November 1992, it handed over power to a metamorphosed version of itself, the National Democratic Congress (NDC) government, with now civilian John Jerry Rawlings as president.

Thus, between 1957, when Ghana became independent, and January 7, 1993 when the new civilian government of Rawlings took effect, Ghana had been ruled under four military governments, with a total of 22 years and 3 months, and three civilian governments, which shared a total of 13 years and 9 months in office. The pattern of civilian-military cycles was not conducive to fostering the 
growth of democratic culture and practice. It was in such a historical context of constant abortion of democratic institutions and rules of behavior and relapse into authoritarianism (Ninsin, 1998, p. 2) that the transition to democracy in Ghana took place. How did the international community impact Ghana's transition to democracy?

\section{The International Community}

Two dimensions of the international community that had an impact on Ghana's democratic transition were snowballing or demonstration effect, and (implicit) political conditionality. Donor pressure worked in Ghana because the Rawlings government had embarked on the SAP in 1983 supervised by the World Bank and IMF, and had gradually become very dependent on the foreign aid that came as a result of implementing the SAP. When political conditionality for good governance was included, the PNDC government could not reject outright the call to liberalize, and ultimately abandoned its "populist ideas and plans that ran into the constraints of the international system" (Green, 1997, p. 5). In effect, "donor pressure for political reform, whether based on the value of political liberalization in governance and the success of structural adjustment, or their own predilection for particular political regimes, was important both in terms of giving support to internal demands and forcing the government to liberalize" (Jebuni \& Oduro, 1998, p. 40).

In this regard, the following sub-section examines snowballing while the next assesses political conditionality by the World Bank and the IMF.

\section{Snowballing}

Snowballing, or the "demonstration effect", as characterized by Huntington (1991) and others, was one aspect of the international environment's influence on the move to democratization in Ghana ${ }^{2}$. As some have argued (Jebuni \& Oduro, 1998, p. 21), the developments in Eastern Europe and the former Soviet Union, where authoritarian governments were replaced by democratically elected ones, had not only a direct impact on the domestic society, but also were important in explaining the emergence of the international donor community "as a strong and in some cases effective lobby of political reform" (Jebuni and Oduro, 1998, p. 21). The collapse of the Eastern European Socialist bloc and the emergence of democratically elected governments "seriously flawed the logic of the one-party and military autocracies in Africa and the rationale for the ban on multi-partyism" (Jebuni \& Oduro, 1998, p. 21).

In Ghana, for example, officials interviewed stressed the importance of the international community and especially the events that occurred in East Germany in 1989 and the fall of the Soviet Union in 1991 in making the opposition's case as well as that of pro-democracy civil society groups much stronger and worth taken seriously by the PNDC regime. ${ }^{3}$ In addition to the international wind of change that was blowing in the late 1980s and early 1990s, one journalist highlighted problems of neighboring countries as well as lessons of failed states, as factors contributing to the PNDC's decision to embark on the transition to a multi-party democracy. ${ }^{4}$

The overall consensus among prominent members of Ghanaian society was that the transition to democracy and the promulgation of the 1992 Constitution were the result of a combination of internal and external pressure on Rawlings' PNDC. In the words of one interviewee regarding the transition to democracy in Ghana,

Internationally, the breakup of the Soviet Union and the third wave of democracy played roles, but we should not downplay the role of civil society internally. The PNDC was also

2 See also Bratton and van de Walle (1992); Hofmeier (1991).

3 Interview with Mrs. Lucia Quachey, President, Ghana Association of Women Entrepreneurs (GAWE), September 1, 2003; Interview with Dr. Edward Mahama, opposition party People's National Convention (PNC)'s flag-bearer, August 22, 2003; Interview with Dan Botwe, New Patriotic Party (NPP) General Secretary, August 29, 2003; Interview with Ben Ephson, Editor, Daily Dispatch, August 21, 2003.

$4 \quad$ Interview with Ben Ephson, Editor, Daily Dispatch, August 21, 2003.

Legon Journal of the Humanities 28.1 (2017) 
willing to let go and transition to democracy, and in 2000, the big key was that Rawlings stepped down after his two terms of office for John Atta-Mills to run as the NDC presidential candidate; Prof. Mills eventually lost after the second round. ${ }^{5}$

The timeline of external events below buttresses statements made by civil society activists, leaders, and journalists. 1989 was a significant year, because it was the year that the Berlin Wall fell, and the communist regimes of Eastern and Central Europe began to fall in quick succession. Ceausescu's demise in Romania in 1989, after a week-long series of violent riots and protests in late December 1989, showed that societal groups, if persistent and strong, could even overcome authoritarian systems such as communism, and hence other autocracies as well. If Ceausescu of Romania could be "so ignominiously deposed, then perhaps Rawlings was not such a formidable adversary after all " (Nugent, 1996, p. 186).

With the end of the Cold War in 1990, it would seem that Western governments and multilateral donors rediscovered political liberalization as a possible panacea for unimpressive and un-sustained economic reform in Africa (Boafo-Arthur, 1999). Then came 1991, which was a significant year because it marked the breakup of the Soviet Union, and many of its republics began processes of political liberalization and democratization. These global events prompted renewed optimism for regime change in Africa. Beginning with the Republic of Benin, where after a series of strikes and popular demands for a national conference, the incumbent president, Nicephore Soglo, lost in subsequent elections in 1990, one regime after the other faced strikes and street protests, and was forced to accept popular demands for a national conference. These national conferences, once convened, sought to allot to themselves sovereign powers and strip incumbent regimes of their powers to govern (Nugent, 1996; Heilbrunn, 1993).

The main movements toward political liberalization in Ghana began in 1988 with the election of the District Assemblies in 1988 and 1989. First, the PNDC's publication of The "Blue Book" or District Political Authority and Modalities for District Level Elections on July 1, 1987 outlined the regime's philosophy and policy on future political reforms for the country. It laid out a decentralized system of government where the District Assemblies would be elected on a no-party basis to be the highest form of political authority, but also form the basis for any future representative institutions that would emerge at the national level.

The Blue Book's proposals and the District Assembly elections and inauguration were significant because, rather than appeasing or forestalling civil society group demands for more say in economic reform and in politics, they ironically led to calls for proper competitive party elections at all levels of government. This was because opposition pro-democracy groups felt that the government's proposed reforms contradicted their demands and meant that their political rights and freedoms would not be realized (Ninsin, 1996).

Second, the PNDC had earlier created the National Commission on Democracy (NCD) in 1982 to spearhead the evolution to a "true" democracy. In 1990, the NCD held regional public forums throughout the ten regions of Ghana from July to November, to ascertain people's views on "The District Assemblies and the Evolving Democratic Process." The NCD presented its report on the public forums to the PNDC government in March 1991. However, the fact that these public fora were held in the first place was significant, because this was the first time that Rawlings' government had actually tried to discern the views of ordinary people on the political process.

Prior to this, the PNDC had been reluctant to expose both the political reforms and the ERP/SAP to any debate for fear of vocal opposition from workers, students, and radical intellectuals, and thus, until 1990, it did not offer any platform on which this debate could occur (Nugent, 1996, p. 166).

Third, the National Commission on Democracy's (NCD) report regarding the overwhelming preference of Ghanaians for a constitutional multi-party form of government went a long way in

5 Interview with Larry Bimi, Chairman, National Commission on Civic Education, August 25, 2003; see also Ayee (2001). 
compelling a shift in the government's position of reluctance to a participation in a constitutional multiparty form of government. Prior to the submission of the NCD's report, Rawlings had announced an inconclusive and limited transition program on both radio and television in his New Year's address of January 1, 1991, which angered many. In this address, there was a shift in rhetoric, from an insistence that "true" democracy can be achieved only through a grassroots decentralized form of government based on the District Assemblies, to talk of a new constitutional order. It also demonstrated his contempt for a constitutional liberal democratic form of government. Among other things, he stated that:

the NCD has been requested to present its report by the end of March this year to enable the PNDC convene a broad-based national consultative body which would use the report as well as the 1957, 1960, 1969, and 1979 constitutions and other constitutions, as the basis for further consultation... Our eyes are now dimly set on the final phase of our journey as a provisional government and the road to establishing for Ghana a new constitutional order. But I believe we have learned over the years that a Constitution as a mere legal document is of no real value, however fine the language and however lofty the sentiments, unless it is a true reflection and embodiment of the perceptions and noble aspirations of ordinary Ghanaians. $^{6}$

This was the first time that Rawlings had actually spoken of a constitution as part of the move toward a change in the form of government. In spite of Rawlings' long-standing insistence on a "popular democracy", most of the feedback from the public regional forums conducted by the NCD showed that most Ghanaians were not in favor of this non-partisan so-called popular democracy. While most Ghanaians were not against decentralization and the District Assemblies per se, they wanted freedom of participation and association in a competitive, national multi-party government.

Fourth, the PNDC issued its statement on the NCD report in May 1991, in which it accepted the views of the general population in favor of multi-party constitutional rule (NCD Report 1991, p. 36). Thus, the government's Statement highlighted the report's assertion that "Ghanaians see the existence of political parties as an expression of the fundamental freedom of association, but that the operation of future political parties should be shorn of the excesses and iniquities of the past." In the Statement, the PNDC further declared that it would constitute a Committee of Experts to formulate constitutional proposals (Ninsin, 1996, p. 99).

Thus, the Committee of Experts was formed in 1991 to formulate constitutional proposals, a significant liberalizing event in itself. The PNDC also announced that the draft constitution would be submitted to a national referendum. It signed into existence the Consultative Assembly law, which established a broad-based national Consultative Assembly in 1991, to discuss and determine the content and form of the $4^{\text {th }}$ Republican Constitution. This was indeed the precise moment that solidified the change in Rawlings and the PNDC's rhetoric and position. Nugent (1996, pp.199-200) puts it aptly that "this was an extraordinary moment because it amounted to the total abandonment of an alternative vision of democracy (grassroots democracy), with which the PNDC had grappled since the start of the revolution."

It is significant that the PNDC government, in its own words, accepted the wishes of Ghanaians for a future constitutional democratic government, in spite of the fact that the government had for most of the 1980s, resisted such calls by pro-democracy civil society groups. By 1991, however, it was fair to say that the regime was suffering from "pro-democracy pressure fatigue" and had realized that it could not ignore the wishes of majority of Ghanaians. A PNDC regime insider, confirming the above analysis, has argued:

6 Flt. Lt. J.J. Rawlings New Year Broadcast, January 1, 1991. 
A major factor in the PNDC's decision to transition was that after the fall of Communism, African governments could no longer play Western governments against Eastern governments. Secondly, the PNDC had been in office for 10 years (by 1991) and could sense that people wanted change. Prof. Adu-Boahen [1992 presidential contender for the NPP] had become popular with his lectures on the culture of silence. The timing of all the local government reforms, the Blue Book, and the decision to go round the country to solicit views about the type of government - all coincided with the external developments. When the NCD report was written, there was no way they (PNDC members) could deny the people's wishes for multiparty democracy. ${ }^{7}$

Finally, both the international wave of democracy and internal demands for democracy ensured that the transition process moved along until the Consultative Assembly completed its work on March 31, 1992. A referendum was then held on April 28, 1992, and the ban on political party activity subsequently lifted on May 15, 1992 (Ninsin, 1998, p. 65; Daily Graphic March 31, April 28, May 15, 1992). Notably, an Interim National Electoral Commission (INEC) had been inaugurated in February 1992 to oversee the registration of political parties and the conduct of elections. The referendum on the draft constitution saw overwhelming Ghanaian approval for its adoption, paving the way for the registration of political parties by INEC in July 1992 and for competitive general elections, the ultimate liberalizing events, to be held in November and December 1992.

These liberalizing events in 1992 were highly significant because, here was a leader that had been so adamantly against pluralist politics, and who, only two years earlier (in 1990), had emphatically declared in a New Year message that Ghana was not ready for a return to pluralist politics (Africa Confidential, 1990, p. 2) - here he was allowing party registration, a constitution, and competitive elections (see Table 1 below for a timeline of liberalizing events in the late 1980s and early 1990s). The counsel of PNDC members and close confidantes, such as P.V. Obeng, political advisor; Kojo Tsikata, security advisor and close friend of Rawlings; Obed Asamoah, foreign affairs secretary; and Justice D.F. Annan, chairman of the NCD, was also very important, because these were counselors that Rawlings listened to and depended on. Rawlings also felt there would be mass unrest if he tried to continue with military rule. ${ }^{8}$

It is interesting to note an alternative argument made in some quarters that although both civil society and the international environment constituted influences on the government to democratize, it had been the PNDC's intention from the start to establish something permanent ultimately, since it was a provisional government. According to the parliamentary minority leader:

The PNDC regime's intention was to clean out the political environment and transition to a real democratic system and culture where the will of the people would prevail and be reflected in government. That is what led to the decentralization and to the establishment of the District Assemblies, zonal councils, and unit committees. The question is whether they were there (in power) for too long and so became unwilling to hand over (power). But with the above-mentioned pressures (civil society and international) they began to set in place structures for what the people wanted. So they set up the National Commission on Democracy (NCD) that culminated in the Consultative Assembly that led to the 1992 elections. ${ }^{9}$

\footnotetext{
Interview with Paa Kwesi Amissah-Arthur, Accra, December 27, 2005. Interview with Paa Kwesi Amissah-Arthur, Accra, December 27, 2005.

Interview with Honorable Alban Bagbin, Minority Leader of Parliament and NDC Member of Parliament, September 5, 2003.
} 
Table 1. Snowballing: Main Events In Eastern Europe And Main Liberalizing Events In Ghana (1988-1992)

\begin{tabular}{|c|c|c|c|}
\hline DATE & $\begin{array}{l}\text { MAIN EVENTS IN } \\
\text { EASTERN EUROPE } \\
\text { AND THE FORMER } \\
\text { SOVIET UNION }\end{array}$ & DATE & $\begin{array}{l}\text { MAIN } \\
\text { LIBERALIZING } \\
\text { EVENTS IN } \\
\text { GHANA } \\
\end{array}$ \\
\hline $1988 ; 1989$ & $\begin{array}{l}\text { Dissatisfaction, from } \\
\text { within some Eastern } \\
\text { European communist } \\
\text { countries, with closed } \\
\text { societies and markets } \\
\text { and authoritarian } \\
\text { practices; Glasnost and } \\
\text { Perestroika under } \\
\text { Gorbachev in the USSR } \\
\text { (began in 1986); } \\
\text { beginning in 1989, } \\
\text { many Eastern European } \\
\text { countries began } \\
\text { peaceful transitions to } \\
\text { democracy }\end{array}$ & July $18-31,1988$ & $\begin{array}{l}\text { Exhibition of voters } \\
\text { register for } \\
\text { impending First } \\
\text { District Level } \\
\text { elections }\end{array}$ \\
\hline $\begin{array}{l}\text { Nov. 9-10, 1989; } \\
\text { October 3, } 1990\end{array}$ & $\begin{array}{l}\text { Berlin Wall fell; East } \\
\text { Germany eventually } \\
\text { united with West } \\
\text { Germany }\end{array}$ & $\begin{array}{l}\text { December 6, 1988; } \\
\text { February 28, } 1989\end{array}$ & $\begin{array}{l}\text { First District Level } \\
\text { elections organized } \\
\text { by the NCD for } 110 \\
\text { districts }\end{array}$ \\
\hline $\begin{array}{l}\text { Dec. 22, 1989; Dec. } \\
25,1989\end{array}$ & $\begin{array}{l}\text { Romania; Ceausescu's } \\
\text { communist } \\
\text { authoritarian } \\
\text { government brought } \\
\text { down after week-long } \\
\text { series of violent riots } \\
\text { and protests; he and his } \\
\text { wife, Elena, were } \\
\text { executed }\end{array}$ & $\begin{array}{l}\text { January 13-March } \\
17,1989\end{array}$ & $\begin{array}{l}\text { Inauguration of } \\
\text { First District } \\
\text { Assemblies }\end{array}$ \\
\hline 1990 & $\begin{array}{l}\text { Fall of the Iron Curtain } \\
\text { and the end of the Cold } \\
\text { War }\end{array}$ & $\begin{array}{l}\text { July 5-November 19, } \\
1990\end{array}$ & $\begin{array}{l}\text { Regional forums on } \\
\text { the theme: "The } \\
\text { District Assemblies } \\
\text { and the Evolving } \\
\text { Democratic } \\
\text { Process" }\end{array}$ \\
\hline \multirow[t]{2}{*}{1991} & $\begin{array}{l}\text { The fall of the Soviet } \\
\text { Union and its } \\
\text { breakdown into several } \\
\text { republics, many of } \\
\text { which began } \\
\text { liberalizing and } \\
\text { democratizing } \\
\text { processes, including } \\
\text { Russia }\end{array}$ & March 25, 1991 & $\begin{array}{l}\text { NCD presents its } \\
\text { report on the } \\
\text { regional forums } \\
\text { conducted across } \\
\text { the } 10 \text { regions in } \\
1990\end{array}$ \\
\hline & & May 13, 1991 & $\begin{array}{l}\text { PNDC government } \\
\text { issues its statement } \\
\text { on the NCD report. } \\
\text { Consultative } \\
\text { Assembly Law }\end{array}$ \\
\hline
\end{tabular}


Gyekye-Jandoh / Legon Journal of the Humanities (2017) 46-61

\begin{tabular}{|c|c|c|c|}
\hline & & & $\begin{array}{l}\text { signed. } \\
\text { Constitutional } \\
\text { Committee of } \\
\text { Experts appointed. }\end{array}$ \\
\hline & & August 26, 1991 & $\begin{array}{l}\text { Inauguration of } \\
\text { Consultative } \\
\text { Assembly to } \\
\text { consider } \\
\text { Constitutional } \\
\text { Draft Proposals by } \\
\text { the Committee of } \\
\text { Experts }\end{array}$ \\
\hline & & November 8, 1991 & $\begin{array}{l}\text { Promulgation of } \\
\text { Interim National } \\
\text { Electoral } \\
\text { Commission } \\
\text { (INEC) Law }\end{array}$ \\
\hline & & February 1992 & $\begin{array}{l}\text { Inauguration of } \\
\text { INEC }\end{array}$ \\
\hline & & March 1992 & $\begin{array}{l}\text { Consultative } \\
\text { Assembly finishes } \\
\text { its work }\end{array}$ \\
\hline & & April 28, 1992 & $\begin{array}{l}\text { Referendum on the } \\
\text { Draft Constitution }\end{array}$ \\
\hline & & May 18, 1992 & $\begin{array}{l}\text { Ban on political } \\
\text { party activities } \\
\text { lifted }\end{array}$ \\
\hline & & July 14-30, 1992 & $\begin{array}{l}\text { Registration of } \\
\text { political parties by } \\
\text { INEC }\end{array}$ \\
\hline & & August 13-30, 1992 & $\begin{array}{l}\text { Political parties } \\
\text { hold Congresses }\end{array}$ \\
\hline & & November 3, 1992 & $\begin{array}{l}\text { Presidential } \\
\text { elections held, in } \\
\text { which Rawlings } \\
\text { and his NDC won }\end{array}$ \\
\hline & & December 29, 1992 & $\begin{array}{l}\text { Parliamentary } \\
\text { elections held, } \\
\text { which were } \\
\text { boycotted by the } \\
\text { opposition }\end{array}$ \\
\hline
\end{tabular}

Source: Information on Ghana adapted from Ninsin, K. (Ed). (1998). Ghana: Transition to Democracy. Accra, Ghana: Freedom Publications.

What is not mentioned by the minority leader of Parliament, however, is the fact that the NCD was created in 1982 while the Consultative Assembly did not convene and was not even seriously discussed until 1991, nine years after the creation of the NCD. The delay in democratizing, and subsequent ambiguity regarding the type of government system to have gives credence to the notion that the regime would not have transitioned to a multi-party democracy had there not been substantial international and internal pressure, and had it not been expedient for Rawlings and his followers, who realized, in their calculations, that they might actually be able to win multi-party elections if they played their cards right and maintained a tight control over the transition program (Ninsin, 1996, p. 57; Nugent, 1996). 
Interestingly, in an August 1991 address, Rawlings alluded to the influence of the international environment on the extent of political reforms toward democracy undertaken by the PNDC. In his words:

\begin{abstract}
We should also give thanks to all those whose efforts have in diverse ways contributed to the attainment of the stage we have now reached... The last decade of the twentieth century will certainly be remembered as one of the most spectacular and eventful of transitional times. We have seen the growth of détente between the seemingly rigid power blocs of East and West. We have seen the reunification of Germany. And we are witnesses to the changes taking place in the Soviet Union. In many countries on our own continent, various political and administrative structures are facing their first challenges in decades. These challenges are characterized by manifestations of mass discontent and dissatisfaction with systems, which had long failed to provide their people access to the decision-making process. $^{10}$
\end{abstract}

The above statements by Rawlings demonstrate that by mid-to-late 1991, he was aware of the enormous impact of external events on other African countries and global developments. Hence, snowballing or the demonstration effect provided an impetus for the eventual transition to democracy led by Rawlings and the PNDC. It was no accident that the major liberalizing events took place between 1989 and 1992, when liberalizing events occurred in Eastern Europe and the former Soviet Union.

It must be noted, however, that while some other African countries also felt the demonstration effect, what made Ghana's transition to democracy more unique and interesting - was the extent to which Rawlings engaged with the World Bank/IMF. Leadership agency (Linz \& Stepan, 1978; Diamond, Linz, \& Lipset, 1996), and not just structural factors of the international system (Skocpol, 1985, 1989), also mattered. This is because Rawlings actually chose between engaging with the World Bank/IMF and how deep this engagement should be, and not engaging at all, or partially engaging on a more superficial level. Rawlings also did not have to democratize; he could have dug in deeper and resorted to more repression, and continued to force his own slow pace of reforms toward a "true" democracy. The fact that he chose to engage with the World Bank/IMF beginning in the mid-1980s, and then later took the democratic transition route can be explained through a look at circumstances that beset his regime in the early days of the "revolution", as well as the increased costs of crackdown that came with the territory of an extensive dependence on the World Bank/IMF. In other words, within the structural context in which he found himself, there was room for agency, for Rawlings to make some choices. The costs of crackdown were, in the end, perceived to be higher than that of giving in to multi-party democracy (Nugent, 1996).

\title{
Political Conditionality
}

It must be emphasized that the information garnered in this section were from people who had really been there, had worked with or been involved with the World Bank/IMF, providing good evidence of implicit political conditionality. The change in Western governments' lending policies by the late 1980s to include political liberalization was exemplified by the United States Agency for International Development (USAID), other bilateral donors, and the World Bank (Jebuni \& Oduro, 1998, p. 21). USAID and others were even more upfront, than the World Bank, about the need for democracy. In the late 1980s, for example, the USAID director in Ghana went to see the PNDC Deputy Finance minister about furthering democracy. ${ }^{11}$ In the view of one World Bank official, however,

10 Ninsin, 1996, p. 119-120; Rawlings, Inaugural Address on the Occasion of the First Session of the Consultative Assembly, August 26, 1991.

11 Interview with Paa Kwesi Amissah-Arthur, Accra, December 27, 2005. 
There was no explicit political conditionality put out by the World Bank. Rather, Jerry Rawlings and his group decided themselves to democratize due to pressure from within Ghana itself for the PNDC government to democratize and the democratic winds blowing worldwide in the late 1980s and early 1990s. Were the World Bank to give political liberalization conditionalities, President Museveni of Uganda would not still be in power in Uganda. The fact that he is still in power even though his country receives aid from the World Bank demonstrates the reality that democracy is not necessary for the World Bank's facilitation of economic development. ${ }^{12}$

But there was implicit political conditionality from the World Bank/IMF in the form of calls for good governance, although they did not specify any clear political liberalization programs that had to be embarked upon by the PNDC. There is a difference between good governance and party politics or democracy. Good governance is concerned with how to make "economic development inclusive, consultative, and operating under the rule of law, local government and decentralization." 13

While good governance in the World Bank's parlance is different from democracy, the article argues that the World Bank implicitly placed a political conditionality for aid on the PNDC in its calls for good governance. The key aspects of 'good governance' - the rule of law, consultative and inclusive economic development, for example - presume political regimes which are more open and which allow criticism of policy to secure better use of resources and less corruption. These aspects of "good governance", ultimately, can best be realized under multi-party democracy. This is how good governance relates to democracy.

In general, then, although not made explicit, democratic transitions were viewed as necessary for improving the credibility of such donor programs as the widespread structural adjustment programs, and creating the enabling environment for better responses (Jebuni \& Oduro, 1998, p. 37) in many an African country in the 1980s and 1990s. Donors were themselves influenced, and their confidence boosted, by the end of the Cold War and the absence of any viable global competitor to democracy, to push for political reform as an important means of realizing stable and effective economic programs. According to one PNDC official,

After the fall of Communism, we began to hear more and more about good governance and democracy, because they (Western governments/multilateral institutions) now had no ideological battles to fight. At the Annual Meeting in Seoul in 1988, the World Bank asked serious questions about democracy, such as what the role of civil society was in the economic reforms being undertaken in Ghana. ${ }^{14}$

The World Bank, though careful to distance itself from the hypothesis that a link between political regime type and economic performance exists (World Bank, 1992), nevertheless has been in the forefront of the call for sound economic management, which, it argues, requires good governance. Good governance is explained in the World Bank's 1989 study on Africa thus:

Underlying the litany of Africa's development problems is a crisis of governance. By governance is meant the exercise of political power to manage a nation's affairs. Because countervailing power has been lacking, state officials in many countries have served their own interests without fear of being called to account....This environment cannot readily support a dynamic economy (World Bank, 1989, p. 601).

12 Interview with Amarkwei Amar, World Bank official, February 11, 2005.

13 Interview with Amarkwei Amar,World Bank official, February 11, 2005.

14 Interview with Paa Kwesi Amissah-Arthur, Accra, December 27, 2005. 
In the view of the Bank, therefore, the absence of good governance proved to be particularly damaging to the "corrective intervention" role of government (World Bank, 1992, p. 10), and could explain the slow response to policy reform. Multi-party democracy in particular, was favored to provide good governance because it had competing political parties that could articulate alternative options, a multi-party parliament that could provide a venue for scrutiny of government expenditures and programs, and a freer press and open debate that would force governments to be more transparent and accountable for their actions (Jebuni \& Oduro, 1998, p. 37).

\section{Rawlings' PNDC, the World Bank/IMF, and How the Structural Adjustment Program (SAP) Contributed to a Change in Governance in Ghana}

What made Ghana different from other African countries was its relationship with the World Bank and its single-minded implementation of the ERP/SAP. Ghana became known as the darling of the IMF, and its implementation of the SAP illuminates the way in which implicit political conditionality from the Bank/IMF helped promote democracy: by increasing Ghana's dependence on foreign aid from the Bank/IMF and thus deepen its vulnerability to the call for "good governance" as a requisite for additional infusions of aid. This worked to constrain Rawlings by increasing the costs of crackdown - withdrawal of aid; tarnished international reputation; and possibly the demise of his regime - aiding him in the decision not to dig in further but to liberalize.

Regarding World Bank policy, another World Bank economist has made it clear that the Bank/IMF did not impose any precise political conditionality:

The World Bank did not directly insist that Ghana change from military to civilian rule, but it promoted "good governance" for many years. Good governance has many dimensions - political, economic, social accountability - and the Bank tries to promote all these aspects of governance progressively. The Bank has a rating under Country Policy and Institutional Assessment (CPIA). This assessment is often shared with governments, where based on certain criteria such as the extent of rule of law, human rights protection (basically democratization), particular countries are given more aid if they are perceived to be progressing with regard to the criteria for the assessment. In effect, there is no hard and fast rule about not supporting military regimes, but when the good governance conditions are adhered to, aid is scaled up. Of relevance to Ghana is the fact that promotion of good governance was a key concern under the SAP program conditions. Under the SAP, a whole list was given of what needed to be done and the time allotted. If the country agreed, then the loan was approved and the country had to implement the conditions. ${ }^{15}$

One may therefore ask how the SAP contributed to democratization in Ghana. The SAP is related to democracy in the sense that although the Bank/IMF never explicitly discussed human rights issues with Rawlings, or stressed that democracy mattered in the early 1990s, Rawlings "understood that to get continuous flow of money from the IMF, he needed to be less authoritarian and have a more open society. He was also very close to President Bill Clinton, who encouraged him on the democratic path. Without money, Rawlings' government would have been weakened, and since the U.S. had to agree to loans, Rawlings' move to democracy pleased the U.S. and opened the doors for further aid." 16 This shows that Rawlings was concerned about his international reputation, but for more instrumental reasons, the most important of which were the further infusions of aid and therefore the more likely survival of his regime.

By the start of the SAP in 1983, Ghana had experienced a continuous decline in Gross Domestic Product (GDP) growth due to policies that resulted in an accelerating rate of inflation, a control system that failed to supply commodities in sufficient quantities or at controlled prices, and urban unrests, all

15 Interview with Daniel Boakye, Economist, World Bank, September 17, 2003.

16 Interview with Eugene Nyambal, Senior Strategy Officer, International Finance Corporation (IFC), November 5, 2005.

Legon Journal of the Humanities 28.1 (2017) 
beginning in 1975. To placate urban groups, government expenditures financed by borrowing from the banking system increased (Jebuni \& Oduro, 1998, p. 23). Notably, the policy change to the World Bank/IMF sponsored SAP occurred as a result of an internal struggle in the PNDC which marginalized the anti-reform elements, rather than as a result of any compromise (Jebuni \& Oduro, 1998, p. 26). These ultra-leftists were brazenly opposed to any form of relationship with the Bank/IMF (BoafoArthur, 1999, p. 14). Even after the purge of the ultra-leftists in December 1982, Nugent (1996, p. 97) argues that the PNDC's ideological definition still involved some trial and error. The Rawlings regime's turn to the West and the ERP/SAP in 1983 was a major policy reversal, and starkly contrasted with its earlier Neo-Marxist ideas.

Jebuni and Oduro (1998, p. 26) highlight the reasons why the PNDC adopted a liberal economic system: the failure of Rawlings' populist economic strategy, the disappearance of rents, and the threat to the survival of the regime. Others have also pointed to the absence of significant assistance from Libya, and an abortive trip to Eastern Europe and Cuba to solicit financial support, as explanation for this perceptible shift in perspective (Hansen, 1987). Rawlings also had to deal with drought and bush fires, as well as the return of more than 1 million Ghanaians from Nigeria in 1983 (Tsikata, 2001, p. 79; Nugent, 1996).

From 1984 to 1989 , foreign exchange availability was the binding economic constraint. The PNDC government needed more foreign aid money for programs and various sectors such as agriculture and education. It is clear therefore that indeed, Ghana needed Bank/IMF aid in the 1980s and 1990s to meet various needs and as a corollary, sustain the Rawlings regime.

Implicit political conditionality and democracy came up mostly in discussions at the Ministry of Foreign Affairs and the embassies. It was not coherent or organized in any way - in the sense that "we need you to do this and that or else". Rather, the Rawlings economic team just "got snapshots or single interventions, but it was still clear that democracy issues were important to Western governments and multilateral institutions." ${ }^{17}$ The economic affairs technocrats and the Bank/IMF, however, mostly focused on development issues in their negotiations.

\section{What Made Ghana/Rawlings the Darling of the Bank/IMF?}

When SAP lending was introduced by the IMF in the 1980s, 24 African countries embarked upon the programme with the aim of improving poor policies that accounted for the 15 percent decline in Africa's GDP per capita between 1977 and 1985 (World Bank, 1994). By 1993, SAPs were being implemented in 36 Sub-Saharan African debtor countries (Ibhawoh, 1999). The adoption and implementation of the ERP/SAP in Ghana from mid-1983 ironically earned Ghana the title of "darling of the Bank/IMF". Why? Simply put, it was first, the PNDC's successful implementation of adjustment, in terms of macroeconomic indicators. Additionally, an official of one of the Bank's institutions has highlighted that Rawlings became the darling of the Bank/IMF because:

although facing a deep economic crisis, African countries, especially the Francophone countries, were reluctant to embark on the SAP; Rawlings was one of the first to volunteer because the Ghanaian economy was in shambles. To reinforce and consolidate his own power base, he went to seek international assistance. ${ }^{18}$

Second, the Bank/IMF "found in Rawlings the tough-mindedness that, in their thinking, was the most appropriate prerequisite, in the 1980s, for the pursuit of such tough economic policies in Africa...consequently, Rawlings became a bridgehead through whom the long-term efficacy of adjustment policies in Africa was experimented" (Boafo-Arthur, 1999, p. 2). In fact, the new 'technocratic staff' that was doggedly in favor of the SAP, led by Dr. Kwesi Botchwey, the finance minister, worked in close collaboration with World Bank officials and foreign consultants who were

17 Interview with Paa Kwesi Amissah-Arthur, Accra, December 27, 2005.

18 Interview with Eugene Nyambal, Senior Strategy Officer, International Finance Corporation (IFC), October 28, 2005. 
often found in the government ministries. In 1987 alone, the World Bank had over 40 missions to Ghana (Riddel, 1992).

The PNDC regime was propped up with steady loan inflows without a single condemnation of its domestic intimidating tactics throughout the 1980s in order to demonstrate the efficacy of the Bank/IMF's new thinking on how best to save and develop an economy in crisis through structural adjustment (Boafo-Arthur, 1999; Callaghy, 1989). The IMF bent its rigid rules on program application in some instances, just in order to ensure the political survival of Rawlings (Martin, 1991). It gave maximum support to the PNDC regime perhaps because of the initial success and impressive outcome of the policies (Anyemedu, 1993; Rothchild, 1991; Toye, 1991), which strengthened its resolve to make a success of Rawlings, one of the few African leaders to have followed so closely and singlemindedly its economic reform tenets.

The international financial institutions' (IFIs) unwavering support for Rawlings in implementing adjustment regardless of his human rights record explains why it was difficult for Rawlings to conceive of an about-turn against these IFIs when implicit political conditions were added in 1989/1990. Also, if Rawlings had continued on a repressive path, "local conditions would not have been good for any long-term developmental work, and the Bank/IMF would probably have not given the government much money." "Evidence of this prognosis in the form of documentation is limited, but interviews with officials from the Ministry of Finance and the World Bank lend support to this argument.

Clearly, from the evidence above, it would seem that the World Bank did not stress the adoption of Western democracy per se, particularly throughout the 1980s, but because Rawlings was so engaged with the IFIs through the SAP, he nevertheless became subsequently constrained on the path towards good governance and democracy.

\section{Conclusion}

After 1992, and once the democratization process was in motion, the international community's influence did not suddenly disappear, but was channeled in an almost behind the scenes supportive role. Bilateral and multilateral donors, especially Britain, Canada, France, Germany, the USAID, and the World Bank, contributed towards the smooth running and quality of elections in 1992, 1996, 2000 and beyond by supplementing funding for the operations and logistics of the Electoral Commission, and by helping to fund some domestic civil society organizations (CSOs) that monitored the elections.

Wright (1990) has highlighted the fact that the ERP/SAP implemented by Rawlings ironically fostered continued heavy dependence on foreign development assistance, and this, in her view, tainted the limited success Ghana achieved under the SAP. With a population of a little more than 14 million in 1990, Ghana received more than $\$ 500$ million a year in aid, and the International Development Association contributed more to Ghana than to any other country except China and India. Such continued dependence definitely exerted some constraints on Rawlings before the transition to democracy and on his subsequent actions once in office as an elected president, in an era of Bank/IMF resurrected ideas of the importance of an enabling and pluralistic political environment for successful economic reform.

The international community's impact on Ghana's gradual democratization has been shown through the importance of "leverage" in the form of political conditionality (Levitsky \& Way, 2005; 2010) viz. Rawlings' implementation of the ERP/SAP, and through the snowballing effect of the global democratization wave, which combined to convince Rawlings of the need to liberalize politically. The international factor worked from above to raise the costs of crackdown by the Rawlings regime. Structure and agency combined to explain Rawlings' decision to democratize, but on his own terms and after careful calculations of the likelihood of keeping his job, this time as an elected civilian president.

19 Interview with Paa Kwesi Amissah-Arthur, Accra, December 27, 2005. 


\section{References}

Adedeji, J.L. (2001).The legacy of J.J. Rawlings in Ghanaian politics, 1979-2000.African Studies Quarterly.Retrieved from http://www.africa.ufl.edu/asq/v5/v5i2al.htm

Africa Confidential(1990) 31 (7), 2-3.Retrieved from http://www.africa-confidential.com/browse-bycountry/id/22/

Anyemedu, K. (1993). The economic policies of the PNDC. In E. Gyimah-Boadi (Ed.), Ghana under PNDC rule (pp.13-47).Dakar: CODESRIA.

Ayodele, T., Cudjoe, F., Nolutshungu, T.A. \& Sunwabe, C.K. (2005).African perspectives on aid:Foreign assistance will not pull Africa out of poverty.Cato Institute Economic Development Bulletin, Project on Global Economic Liberty, 2 (September), 1-4.

Bermeo, N. (1990).Rethinking regime change.Comparative Politics, 22 (April), 359-377.

Boafo-Arthur, K. (1998). The international community and Ghana's transition to democracy. In K.A. Ninsin (Ed.),Ghana: Transition to Democracy (pp.135-163). Dakar, Senegal: CODESRIA.

Boafo-Arthur, K. (1999).Structural adjustment programs (SAPS) in Ghana: Interrogating PNDC's implementation. West Africa Review, 1(1), 15-35.

Bratton, M. \& van de Walle, N. (1992). Toward governance in Africa: Popular demands and State responses. In G. Hyden \& M. Bratton (Eds.), Governance and Politics in Africa (pp. 2755).Boulder, CO: Lynne Rienner.

Callaghy, T. (1989).Towards state capability and embedded liberalism in the Third World:Lessons for adjustment. In J. Nelson (Ed.), Fragile coalition: The politics of economic adjustment (pp. 115138). New Brunswick, NJ: Transaction Books.

Daily Graphic, March 31, April 28, May 15 (1992).

Decalo, S. (1992).The process, prospects, and constraints of democratization in Africa. African Affairs, 91 (362), 7-35.

Diamond, L., Linz, J. \& Lipset, S.M. (1995).Politics in developing countries: Comparing experiences with democracy. Boulder, CO: Lynne Rienner.

Frimpong-Ansah, J.A. (1991).The vampire state in Africa: The political economy of decline in Ghana. London, UK: James Currey.

Geddes, B. (1991).A game theoretic model of reform in Latin American democracies. American Political Science Review, 85 (2), 371-392.

Green, D. (1997). Democracy, adjustment, and the 'internationalization of the State' in Ghana. Accra, Ghana: Institute of Economic Affairs. Occasional Papers 7.

Gyimah-Boadi, E. (1990).Economic recovery and politics in PNDC's Ghana. The Journal of Commonwealth and Comparative Politics, 28(3), 328-343.

Haggard, S. \& Kaufmann, R. (1995). The political economy of democratic transitions. Princeton, NJ: Princeton University Press.

Hansen, E. (1987).The State and popular struggles in Ghana, 1982-1986. In P. Anyang' Nyong'o (Ed.), Popular struggles for democracy in Africa (pp. 162-180). London, UK: Zed.

Heilbrunn, J. (1993). Social origins of the national conferences in Benin and Togo. Journal of Modern African Studies, 31 (2), 277-299.

Hofmeier, R. (1991). Political conditionalities on development aid in Africa: A new form of intervention or legitimate support for democratic efforts? Economics, 44, 100-111.

Hutchful, E. (1992).The international dimensions of the democratization process in Africa. Dakar, Senegal: CODESRIA.

Ibhawoh, B. (1999).Structural adjustment, authoritarianism, and human rights in Africa. Comparative Studies of Asia, Africa, and the Middle East, 19 (1), 158-167.

Jebuni, C. \& Oduro, A. (1998 South).Structural adjustment program and the transition to democracy. In K.A. Ninsin (Ed.), Ghana: Transition to Democracy (pp. 21-48).Dakar, Senegal: CODESRIA. 
Levitsky, S. \& Way, L. (2003).Ties that bind? International linkage and competitive authoritarian regime change in the post-Cold War era. Speech delivered at the Annual Meeting of the American Political Science Association, August, Philadelphia.

Levitsky, S. \& Way, L. (2005). International linkage and democratization. Journal of Democracy, 16 (3) (July), 20-34.

Levitsky, S. \& Way, L. (2010). Competitive authoritarianism: Hybrid regimes after the Cold War. Cambridge, UK: Cambridge University Press.

Levitsky, S. \& Way, L. (2012). Beyond patronage: Violent struggle, ruling party cohesion, and authoritarian durability. Perspectives on Politics, 10 (4), 869-889.

Linz, J. (2000). Totalitarian and authoritarian regimes. Boulder, CO: Lynne Rienner.

Linz, J. \& Stepan, A. (1978).The breakdown of democratic regimes: Crisis, breakdown and reequilibration. Baltimore, MD: Johns Hopkins University Press.

Linz, J. \& Stepan, A. (1996). Problems of democratic transition and consolidation: Southern Europe, South America, and post-Communist Europe. Baltimore, MD: Johns Hopkins University Press.

National Commission on Democracy (1991).Evolving a true democracy: A summary of NCD's work towards the establishment of a new democratic order. Accra, Ghana: Government Printer.

Ninsin, K. A. (1996). Ghana's political transition 1990-1993: Selected documents. Accra, Ghana: Freedom Publications.

Ninsin, K. A. (Ed.), (1998).Ghana: Transition to democracy. Dakar, Senegal: CODESRIA.

Nugent, P. (1996). Big men, small boys and politics in Ghana: Power, ideology and the burden of history, 1982-1994. London, UK: Printer.

Przeworski, A. (1991). Democracy and the market: Political and economic reforms in Eastern Europe and Latin America. New York, NY: Cambridge University Press.

Riddell, J.B. (1992).Things fall apart again: Structural adjustment programs in Sub-Saharan Africa. Journal of Modern African Studies, 30 (1), 53-68.

Rothchild, D. (1991). Ghana and structural adjustment: An overview .In D. Rothchild (Ed.), Ghana: The political economy of recovery (pp. 3-17). Boulder, CO: Lynne Rienner.

Skocpol, T. (1979). States and social revolutions. Cambridge, UK: Cambridge University Press.

Skocpol, T. (1985). Bringing the state back in: Strategies of analysis in current research. In P. B, Evans, D. Rueschemeyer, \& T. Skocpol. (Eds.), Bringing the State back in (pp. 3-43). Cambridge, UK: Cambridge University Press.

Skocpol, T. (1989). Reconsidering the French revolution in world-historical perspective. Social Research: An International Quarterly, 56(1), 53-70.

Toye, J. (1991). Ghana. In P. Mosely, J. Hannigan \& J. Toye. (Eds.), Aid and power: The World Bank and policy-based lending 2 (pp. 151-200). London, UK: Routledge.

Tsikata, Y. M. (2001). Successful reformers: Ghana. In S. Devarajan, D.R. Dollar, \& T. Holmgren (Eds.), Aid and Reform in Africa: Lessons from Ten Case Studies. Washington, D.C: The World

Bank. Retrieved from http://www. worldbank.org/html/aid/africa/release/chap2. pdf (0409)

World Bank (1989).World Bank Sub-Saharan African report. Washington, DC: World Bank.

World Bank (1990). Ghana progress on adjustment. Washington, DC: World Bank.

World Bank. (1992). Governance and development. Washington, D.C: World Bank.

World Bank. (1994). Adjustment in Africa: Reforms, results, and the road ahead. Washington, DC: World Bank.

Wright, N. E. (1990). Disastrous decade: Africa's experience with structural adjustment. Multinational Monitor, 11(4), (April).Retrieved from http://www.multinationalmonitor.org /hyper/issues/1990/04/wright.html 